\title{
The Structure of the Welded Joints between High-Strength Steel USIBOR 22MnB5 and Mild Steel H340LAD+Z140-M-B-O Made by Resistance Spot Welding
}

\author{
Pavol SEJČ, Judita BELANOVÁ, Štefan EMMER
}

\begin{abstract}
The application of different types of materials, e.g. coated high-strength materials and galvanized steels in the manufacturing of car bodies, requires the verification of their weldability. Despite the application of new, unconventional fusion welding technologies (CMT, laser), resistance spot welding holds a dominant position in the production of car bodies of lower and middle class. Resistance welding technology is characterized by a high rate of heating and cooling, thus affecting the final properties of the welded joint. The paper is focused on the structure analysis of the welded joint of high strength steel USIBOR 22MnB5 with Al-Si coating and galvanized mild steel H340LAD+Z140-M-B-O made by resistance spot welding.
\end{abstract}

Keywords: galvanized steel sheets; resistance spot welding; ultra-high strength steels

\section{INTRODUCTION}

The current trend of construction of car body components is focused on applications of various types of materials. Among the most common materials are included galvanized steel sheets with different properties: CarbonManganese Steels, Bake Hardening Steels, Dual Phase Steels, Complex Phase Steels, Ferritic-Bainitic Steels, Martensitic Steels, Boron Ultra High Strength Steels (UHSS-B) [1].

Zinc is applied to the steel sheet as a coating to provide atmospheric corrosion protection. Zinc coatings provide passive barrier protection as well as active cathodic protection. High strength of UHSS steels is obtained not only by alloying, but also by a special process of thermomechanical treatment. Depending on the type of thermomechanical treatment one can achieve a wide interval of yield strength and tensile strength of the material. Yield strength begins at approximately $430 \mathrm{MPa}$ and after treatment and with the contribution of $\mathrm{BH}$ (Bake Hardening) effect it reaches up to $1770 \mathrm{MPa}$. Tensile strength is then moved to $500 \div 2034 \mathrm{MPa}$ [2]. Due to the nature of the heat treatment, UHSS steel is covered with Al-Si coating.

The application of materials with different characteristics enables to reduce the thickness of the sheets of the outer shell body, resulting in total weight savings of the vehicle without reducing the safety and stability. Examples of car body components which are made of high strength steels are shown in Fig. 1. [3]

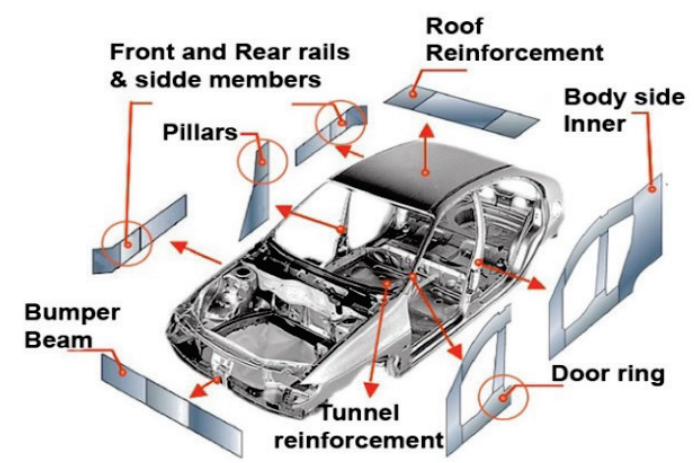

Figure 1 Car body components made of high-strength stee
Based on this, when manufacturing structures such as car body, one should address a topic of weldability of new types of steels, respectively different combinations of materials $[4 \div 8]$.

Currently, various welding techniques are used in car body components welding $[9,10]$. Despite the indisputable advantages of using a concentrated source of energy in the processing of steel sheet $[11,12,18]$, resistance spot welding technology belongs among the most common techniques used when joining thin sheets.

The paper aims to evaluate the structure of welded joints of high strength steel USIBOR 22MnB5 with Al-Si coating and galvanized mild steel H340LAD + Z140-M-B$\mathrm{O}$ by resistance spot welding.

\section{THE METHODOLOGY OF EXPERIMENTS AND EXPERIMENTAL MATERIAL}

For production of testing welded joints a galvanized mild steel sheet H340LAD + Z140-M-B-O (EN 10292) with $1,0 \mathrm{~mm}$ thickness has been used. The average thickness of the $\mathrm{Zn}$ layer was $10 \mu \mathrm{m}$ [4]. As the second material a high-strength steel sheet marked as USIBOR 22MnB5 + AS150 (EN 10131-2.0) has been used with a thickness of $1.0 \mathrm{~mm}$ after thermo-mechanical treatment, which corresponded to hot pressing. The thickness of the protective Al-Si coating on cross-sections of metallographic samples ranged from 25 to $30 \mu \mathrm{m}$. Indicative chemical composition and mechanical properties of experimental materials are mentioned in Tab. $1 \div 4$.

Samples for the production of resistance spot-welded joint were made from the drawn parts used to produce car body components. Mild steel sheet was coated with zinc coatings produced in continuous galvanizing process. AlSi coating for high strength USIBOR steel was affected by the changes caused by the hot pressing regime.

For resistance spot welding, only transferable medium frequency welding gun with built-in transformer type ARO-72500 (S50 56/KVA) was used. In the experiments the following welding parameters were used: welding current of $8 \mathrm{kA}$, welding time of $300 \mathrm{~ms}$ and welding force of $1,5 \mathrm{kN}$. 


\begin{tabular}{|c|c|c|c|c|c|c|c|c|}
\hline \multicolumn{1}{|c}{ Table 1 Chemical composition of galvanized mild steel H340LAD+Z140-M-B-O (max\%) } \\
\begin{tabular}{|c|c|c|c|c|c|c|c|c|c|}
\hline Type & $\mathrm{C}$ & $\mathrm{Si}$ & $\mathrm{Mn}$ & $\mathrm{P}$ & $\mathrm{S}$ & $\mathrm{Al}$ & $\mathrm{Ti}$ & 0,15 & 0,09 \\
\hline H340LAD & 0,10 & 0,50 & 1,00 & 0,025 & 0,025 & 0,015 & 0,15 \\
\hline
\end{tabular}
\end{tabular}

Table 2 Mechanical properties of galvanized mild steel H340LAD+Z140-M-B-O

\begin{tabular}{|c|c|c|c|c|c|c|}
\hline \multirow{2}{*}{ Type } & \multicolumn{3}{|c|}{ Transverse } & \multicolumn{3}{c|}{ Lengthwise } \\
\cline { 2 - 7 } & $R_{\mathrm{e}} / \mathrm{MPa}$ & $R_{\mathrm{m}} / \mathrm{MPa}$ & $A_{80} / \mathrm{min} \%$ & $R_{\mathrm{e}} / \mathrm{MPa}$ & $R_{\mathrm{m}} / \mathrm{MPa}$ & $A_{80} / \mathrm{min} \%$ \\
\hline H340LAD & $340 \div 420$ & $410 \div 510$ & 19 & $320 \div 400$ & $400 \div 500$ & 22 \\
\hline
\end{tabular}

Table 3 Chemical composition of USIBOR 22MnB5+AS150 (\%)

\begin{tabular}{|c|c|c|c|c|c|c|c|c|c|}
\hline $\mathrm{C}$ & $\mathrm{Si}$ & $\mathrm{Mn}$ & $\mathrm{Cr}$ & $\mathrm{Mo}$ & $\mathrm{P}$ & $\mathrm{S}$ & $\mathrm{Ti}$ & $\mathrm{Al}$ & $\mathrm{B}$ \\
\hline $0,20 \div 0,25$ & $0,15 \div 0,40$ & $1,10 \div 1,40$ & $\leq 0,35$ & $\leq 0,35$ & $\leq 0,025$ & $\leq 0,005$ & $0,020 \div 0,050$ & $0,020 \div 0,060$ & $0,002 \div 0,005$ \\
\hline
\end{tabular}

Table 4 Mechanical properties of USIBOR 22MnB5 +AS150

\begin{tabular}{|c|c|c|c|c|}
\hline Type & Treatment & $R_{\mathrm{e}} / \mathrm{MPa}$ & $R_{\mathrm{m}} / \mathrm{MPa}$ & $A 80 / \mathrm{min} \%$ \\
\hline \multirow{2}{*}{ USIBOR 22MnB5+ AS150 } & $\mathrm{Al} \mathrm{Si}-$ dip refined & \multirow{2}{*}{$350 \div 550$} & \multirow{2}{*}{$500 \div 700$} & \multirow{2}{*}{10} \\
\cline { 2 - 5 } & cold or hot rolled & & \\
\hline
\end{tabular}

\section{OBTAINED RESULTS}

Fig. 2 shows a detail view of the weld joint from the side of galvanized mild steel H340LAD + Z140-M-B-O and high-strength steel USIBOR 22MnB5 + AS150. The cross-section of the joint is shown in Fig. 3 and its details in Fig. 4. EDX analysis of selected sites of the weld joint is in Tab. 5 .
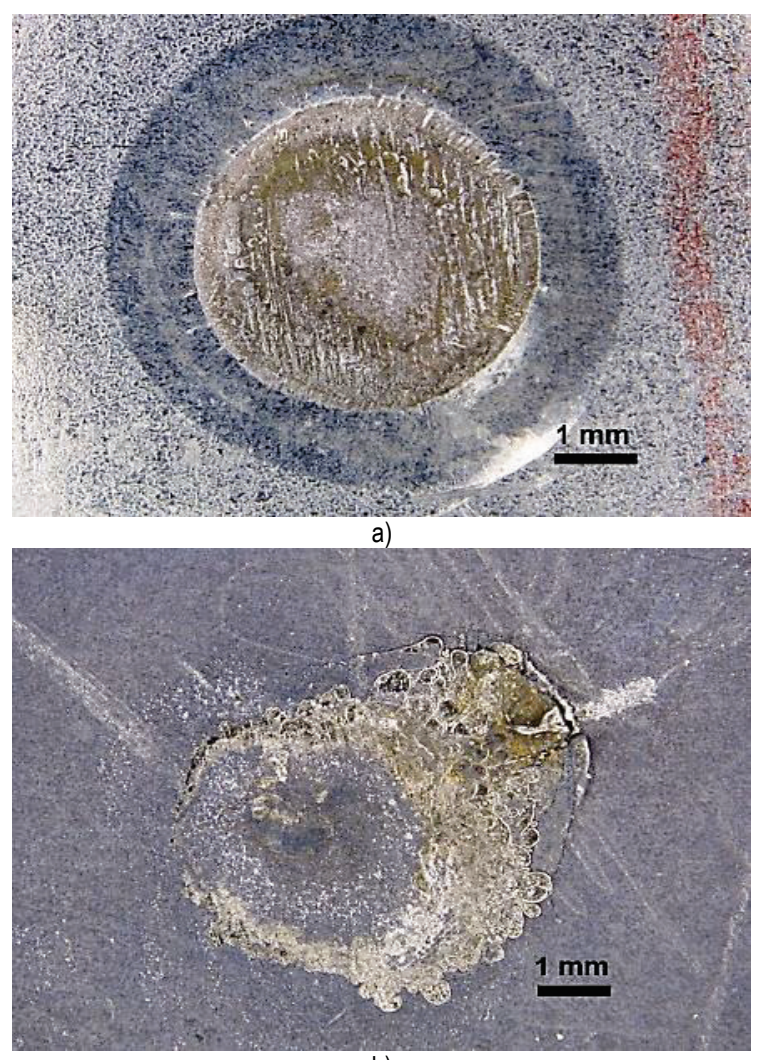

b)

Figure 2 Surface of spot-welded joint from the side of steel: a) H340LAD+Z140 M-B-O, b) USIBOR 22MnB5 +AS150

Diameter of nugget measured on transverse sections reached 5,7 mm (Fig. 3). Its size corresponds to the load bearing (1) expressed as follows [13]:

$$
d \geq 4 \sqrt{h}
$$

where $h$ is sheet thickness.
The resistance spot welding will be significantly influenced by the state of the surface of the welded metal: roughness, finish coating $[14,19,20]$. Surface of hot dip galvanized sheets will consist of a solid solution of $\mathrm{Fe}$ in $\mathrm{Zn}$ (Eta phase). During the manufacturing of the coating by immersion in molten zinc, diffusion of Fe from the sheet metal into the coating occurs. Fe content in the resulting coating will thus increase towards the interface coating steel sheet. A higher content of Fe causes the formation of intermetallic phases of the type $\mathrm{Fe}_{x} \mathrm{Zn}_{y}$ with different physical characteristics (hardness, thermal and electrical conductivity) [14].

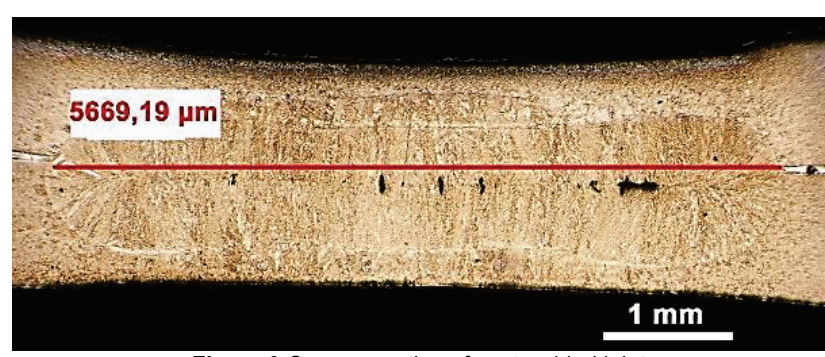

Figure 3 Cross - section of spot welded joint

$\mathrm{Zn}$ has a low melting temperature $\left(420{ }^{\circ} \mathrm{C}\right)$. $\mathrm{Zn}$ evaporation temperature $\left(907{ }^{\circ} \mathrm{C}\right)$ is more than $600{ }^{\circ} \mathrm{C}$ below the melting temperature of low carbon steel (1536 $\left.{ }^{\circ} \mathrm{C}\right)$. During the process of resistance, welding of galvanized steel sheets the surface layer of zinc melts first. The welding force will squeeze molten $\mathrm{Zn}$ layer to the surroundings of the weld, which then solidifies. Fig. 2 clearly shows the location of contact of material with the electrode and the annulus area of the zinc coating which melted during welding and solidified during cooling of nugget. [21]

In the areas where the temperature exceeds $907^{\circ} \mathrm{C}$, the zinc begins to evaporate. In case of improperly selected basic parameters of the welding process (welding current, welding time, welding force), pores or cold joints can occur due to evaporation of zinc (Fig. 3). Given by the low melting evaporation temperatures of $\mathrm{Zn}$, zinc contamination of the weld metal was not observed (Tab. 5).

The main function of Al-Si coating on high strength steel USIBOR $22 \mathrm{MnB} 5+\mathrm{AS} 150$ is to prevent oxidation and decarbonisation of sheet surface during hot pressing $[16,19]$. By heating to $950{ }^{\circ} \mathrm{C}$ for hot pressing diffusion of $\mathrm{Fe}$ into the coating takes place. The Fe diffusion changes 
the chemical composition of the coating through the entire thickness. Since Fe - Al alloy has a higher melting temperature than the original Al-Si coating (about $600^{\circ} \mathrm{C}$ ), during hot pressing the coating enriched with $\mathrm{Fe}$ is not in the liquid state. The structure of the coating - presence of $\mathrm{Al}, \mathrm{Si}$ and $\mathrm{Fe}$-will depend on the heating regime (holding time at the temperature of $\left.950{ }^{\circ} \mathrm{C}\right)$. In a short time $(30$ seconds), the layer will be composed of the five sub-layers with weight percentage of $\mathrm{Al}$ (from the surface): 50, 30, 50, 30 and $10 \%$. The phases $\mathrm{Fe}_{2} \mathrm{Al}_{5}$ and $\mathrm{FeAl}_{2}$ were identified in the sub-layers adjacent to the surface $[16,22]$.

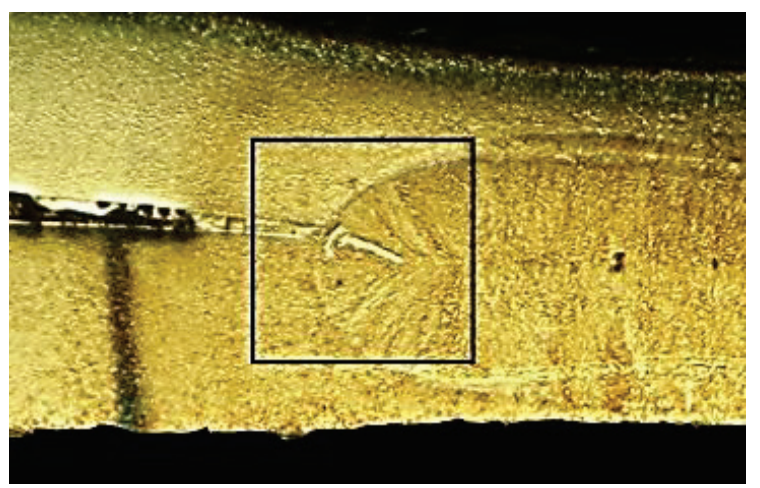

a)

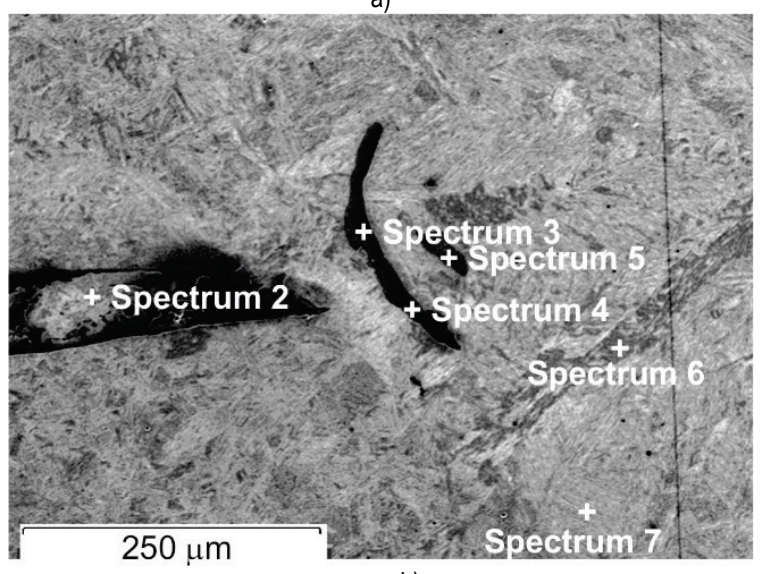

b)

Figure 4 Details of the cross-section of spot-welded joint: a) general view, b) detail of the chosen area

Due to the higher melting temperature of the coating, only point of contact of material with the electrode is visible from the side of high-strength steel USIBOR $22 \mathrm{MnB} 5+$ AS150 on the sheet surface (Fig. 2b).

Joint surroundings is marked by spray of melted coating and its reaction with the air atmosphere without significant heat-affected zone (HAZ). Because the alloys of $\mathrm{Fe}$ - $\mathrm{Al}$ have an evaporation temperature higher than $2000{ }^{\circ} \mathrm{C}$, the coatings based on $\mathrm{Al}-\mathrm{Si}$ will not cause bubbles as in the case of galvanized steel welding.

In the analysis of the cross-section (Fig. 4a) at the nugget edges were identified the phases, which were incoherent with the basic matrix. A detailed analysis of selected sites (Fig. 4b) enabled to observe locally increased content of $\mathrm{Al}$ to $9 \%$ (Spectrum 3 and 4, Fig. 4b, Tab. 5). Al content is in line with the contents of this element in the sub-layer adjacent to the surface of the steel USIBOR $22 \mathrm{MnB} 5+\mathrm{AS} 150$ [16]. The source of inclusions detected at the weld nugget edge was Al-Si coating parts of the highstrength steel sheet.
Table 5 EDX analysis of the selected sites on the cross-section (Fig. 4b)

\begin{tabular}{|c|c|c|c|c|c|}
\hline $\begin{array}{c}\text { Measured } \\
\text { place/Element }\end{array}$ & $\begin{array}{c}\mathrm{Fe} \\
(\text { wt.\%) }\end{array}$ & $\begin{array}{c}\mathrm{Al} \\
\text { (wt.\%) }\end{array}$ & $\begin{array}{c}\mathrm{Mn} \\
\text { (wt.\%) }\end{array}$ & $\begin{array}{c}\mathrm{Si} \\
\text { (wt.\%) }\end{array}$ & $\begin{array}{c}\mathrm{Zn} \\
\text { (wt.\%) }\end{array}$ \\
\hline Spectrum 2 & 98,0 & 0,7 & 1,0 & 0,3 & 0,0 \\
\hline Spectrum 3 & 90,2 & 8,0 & 1,0 & 0,8 & 0,0 \\
\hline Spectrum 4 & 89,7 & 8,6 & 0,9 & 0,8 & 0,0 \\
\hline Spectrum 5 & 95,0 & 3,3 & 1,0 & 0,7 & 0,0 \\
\hline Spectrum 6 & 98,4 & 1,0 & 0,3 & 0,3 & 0,0 \\
\hline Spectrum 7 & 98,4 & 0,3 & 1,0 & 0,3 & 0,0 \\
\hline
\end{tabular}

Weldability of mild and high-strength micro-alloyed steels can be analysed based on several criteria. The basic criteria are the carbon content and carbon equivalent. Although for the modern micro-alloyed steels assessing the weldability in terms of chemical composition standard Pcm is used, for assessing the weldability of steels with higher carbon content $\mathrm{C}=0,15 \div 0,3 \%$ it is more recommended to use a known standard carbon equivalent according to IIW:

$\mathrm{CE}(\mathrm{IIW})=\mathrm{C}+\frac{\mathrm{Mn}}{6}+\frac{\mathrm{Cu}+\mathrm{Ni}}{15}+\frac{\mathrm{Cr}+\mathrm{Mo}+\mathrm{V}}{5}$.

On the other hand, VW standard 01105-1:2007 indicates a condition of suitability of the steel material for the resistance spot welding of carbon content to $0,25 \%$ (max. 0,3\%) [23]. In evaluating the hardness of unalloyed and low-alloyed steel an equivalent according to DVS 2902-2 [24] is recommended for calculating the carbon equivalent:

$\mathrm{CE}=\mathrm{C}+\frac{\mathrm{Mn}}{6}$.

Based on the chemical composition of the material

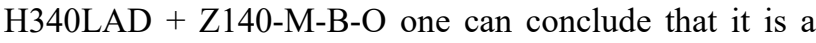
steel with guaranteed weldability - C content $=0,1 \%$, $\mathrm{CE}(\mathrm{IIW})=0,27 \%$. For micro-alloyed steel USIBOR $22 \mathrm{MnB} 5$ (Tab. 1), the resulting value of the carbon equivalent is $\mathrm{CE}(\mathrm{IIW})=0,62 \%$, according to DVS $2902-2$ $\mathrm{CE}=0,48 \%$. As the carbon equivalent CE(IIW) exceeds $0,45 \%$, a high hardness (above $380 \mathrm{HV}$ ) of weld metal and HAZ structure after welding is expected. For this reason, DVS standard 2902-2 (and DVS standard 2905) indicates the maximum hardness in the weld nugget and HAZ 550 HV 0.2 .

Resistance spot welding is characterized by a high cooling rate, which can reach up to $10^{5} \mathrm{C} / \mathrm{s}$. For welding of carbon-manganese steel with carbon content of critical value $(\mathrm{C}>0,2 \%)$ respectively carbon equivalent ( $\mathrm{CE}$ (IIW) $>0,45 \%$ ), this fact will be demonstrated by a high representation of non-equilibrium transformed structures with high hardness - martensite and lower bainite in a melt zone of the weld nugget. To calculate the hardness of the martensitic structure according to the carbon content of steel, we can use the equation [17]:

$\mathrm{HV}=630, \mathrm{CE}_{\mathrm{Y}}+188$

where $\mathrm{CE}_{\mathrm{Y}}$ is carbon equivalent based on Yurioka. 


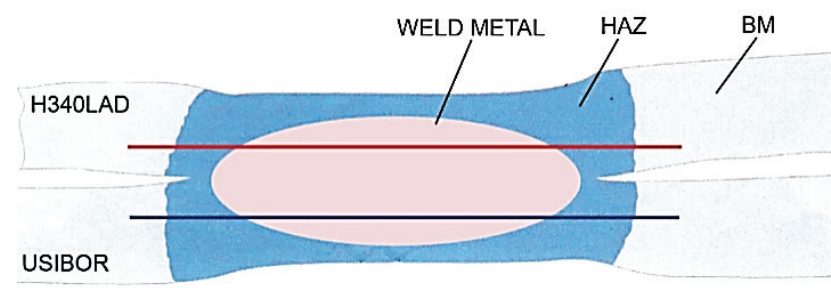

Figure 5 Diagram of micro-hardness measurements on cross-section of spotwelded joint ( $\mathrm{HAZ}$ - heat-affected zone, BM- base material)

Microhardness of the weld joint was measured in two lines - from the side of galvanized mild steel H340LAD +
Z140-M-B-O and from the side of steel USIBOR 22MnB5

(Fig. 5). Microhardness charts are documented in Fig. 6

The structure of the spot-welded joint of galvanized steel H340LAD + Z140-M-B-O with high strength steel USIBOR 22MnB5 + AS150 is documented in Fig. 7.

We assume that the nugget was formed by mixing of equal volume of melted mild steel H340LAD + Z140-M-B-O and high-strength steel USIBOR 22MnB5 + AS150 (Fig. 4a). In the weld metal (WM), there was a reduction in the carbon content compared to its representation in the material USIBOR (Tab. 3), which would affect the hardness of the weld.

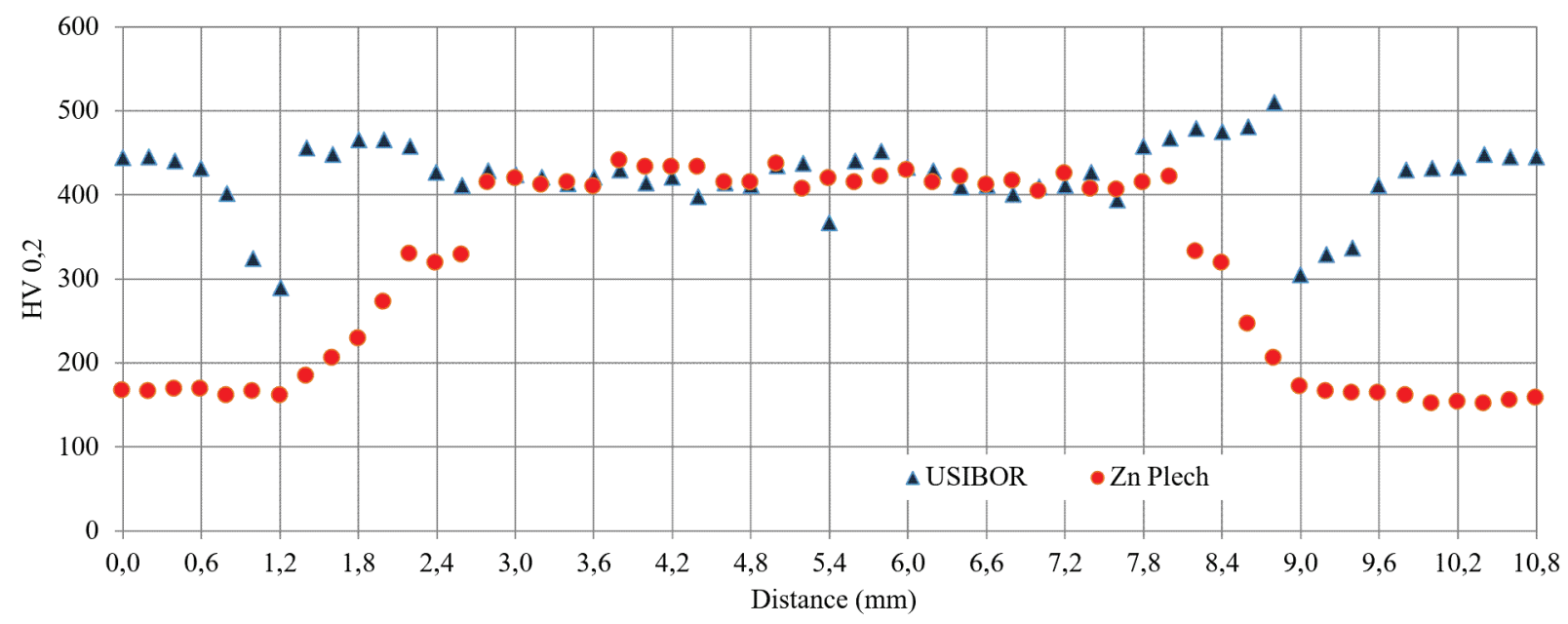

Figure 6 Micro-hardness of spot-welded joint

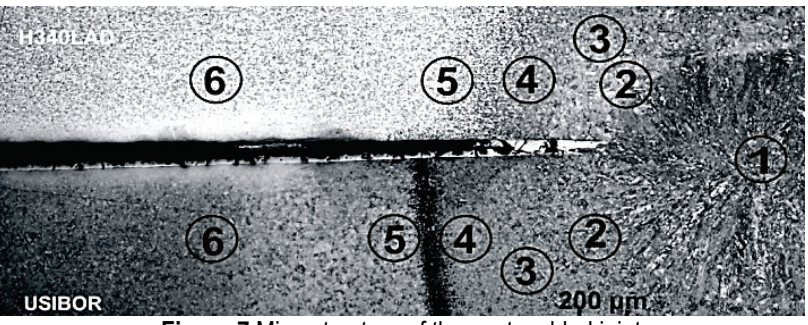

Figure 7 Microstructure of the spot-welded joint

1 - weld metal, 2 - highly-heated HAZ, 3 - low-heated HAZ, 4 - area heated between temperatures $A_{c 3}-A_{c 1}, 5$ - HAZ heated under $A_{c 1}, 6$ - base material

The measured hardness values of WM martensitic structure (Fig. 8a) with an average hardness of $410 \mathrm{HV} 0.2$ were only slightly lower than the hardness of base material USIBOR 22MnB5 + AS150 (Fig. 6).

From the side of high-strength steel USIBOR 22MnB5 + AS150, the structure of highly-heated heat-affected zone (Coarse Grain - CG HAZ) was formed by transformation of austenite which was superheated above temperature $A_{c 3}$ during rapid cooling. The dominant structural component is martensite here as well (Fig. 8b), therefore CG HAZ has the hardness only little bit different from the WM hardness - from 410HV0.2 to 520HV0.2 (Fig. 6).

In the transition region to the base material $(\mathrm{BM})$ at temperatures between $\mathrm{A}_{\mathrm{c} 3}$ and $\mathrm{A}_{\mathrm{c} 1}$ (Fig. 7), only a partial recrystallization of $\mathrm{BM}$ structure occurred. This area is compared to CG HAZ much finer grain (Fig. 9a). Partial austenitizing and subsequent martensitic transformation of the austenite gave rise to martensitic - ferritic structure without changing the hardness compared to CG HAZ (Fig. $6)$.

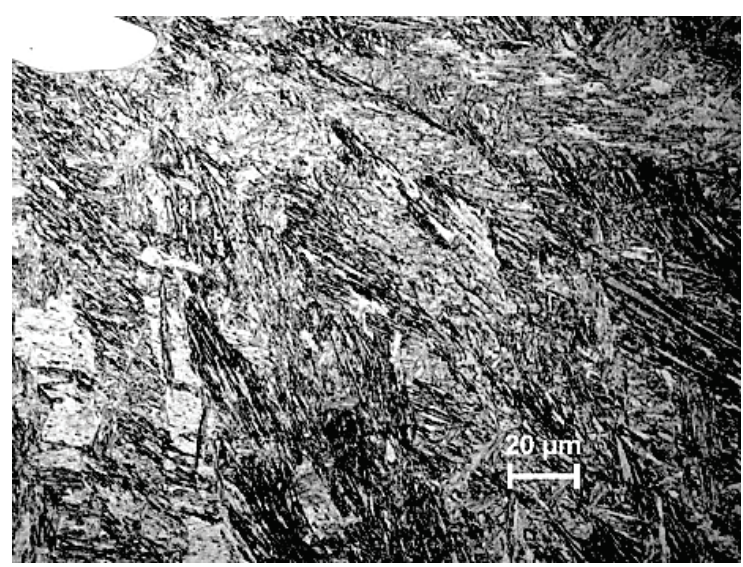

a)

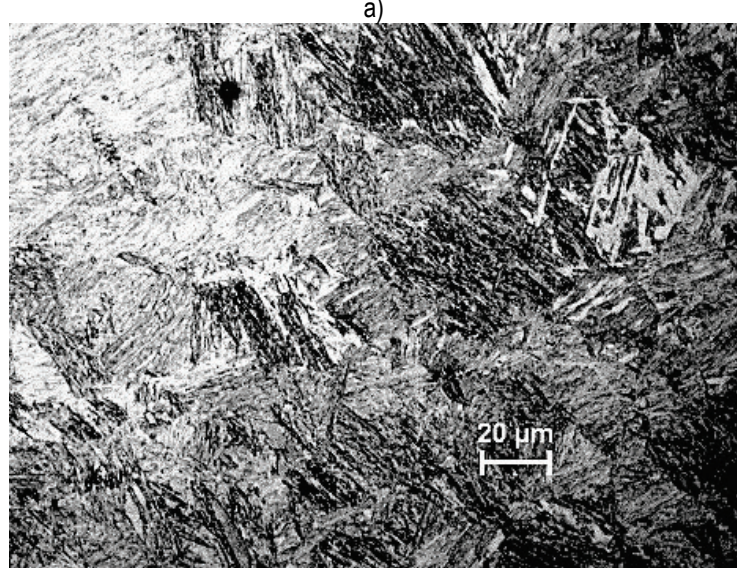

b)

Figure 8 Structure of the joint from the side of high-strength steel USIBOR 22MnB5+AS150: a) weld metal, b) highly-heated HAZ 
A significant decrease in hardness has been made on the area heated just below $\mathrm{A}_{\mathrm{cl}}$ (Fig. 6). The structure is composed of ferrite and tempered martensite with a hardness of 290 to $340 \mathrm{HV} 0.2$ (Fig. 9b).

The hardness of the base material USIBOR 22MnB5 + AS150 was around 445HV0.2 (Fig. 6). The structure was composed of martensite and residual austenite (Fig. 10). The results of the measured hardness of the weld metal structure correspond to the values obtained by calculation using Eq. (4) and correspond to those material properties after the thermo-mechanical treatment (hot pressing) [2].

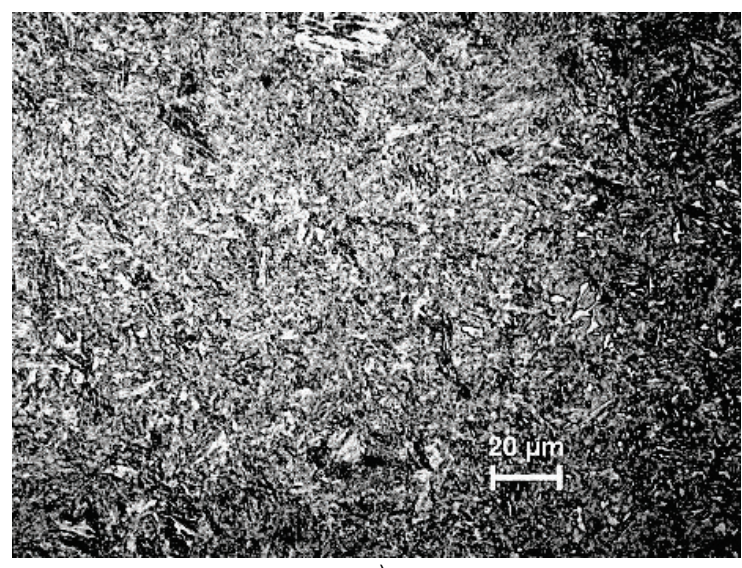

a)

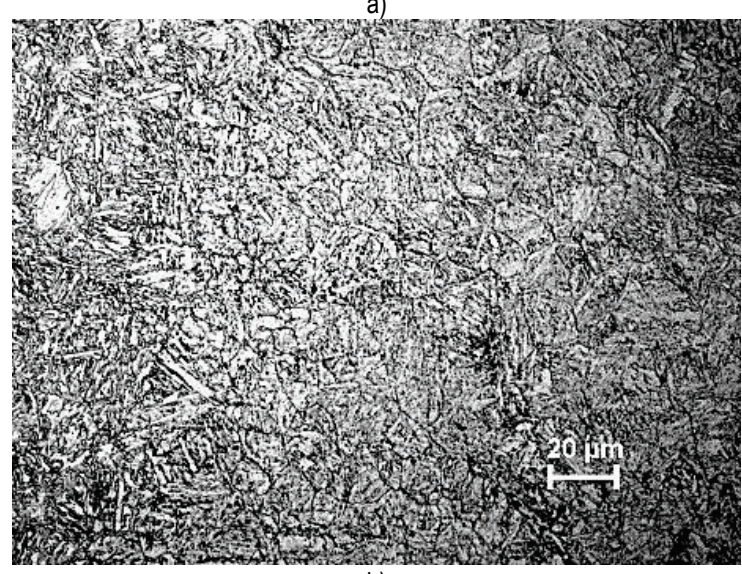

b)

Figure 9 Structure of the joint from the side of high-strength steel USIBOR 22MnB5+AS150: a) HAZ heated between $A_{c 3}-A_{c 1}$, b) HAZ heated slightly below $A_{c 1}$

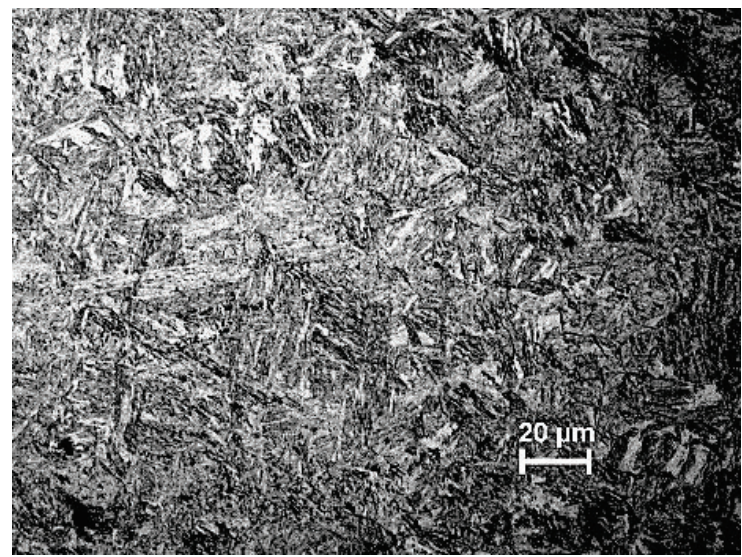

Figure 10 Structure of base material USIBOR 22MnB5+AS150

From the side of the high-strength steel USIBOR $22 \mathrm{MnB} 5+\mathrm{AS} 150$, hardness values of $\mathrm{WM}, \mathrm{HAZ}$ and BM did not exceed the value of $550 \mathrm{HV} 0.2$. We can thus conclude that the maximum hardness criterion according to DVS 2902-2 (resp. DVS 2905) is met.

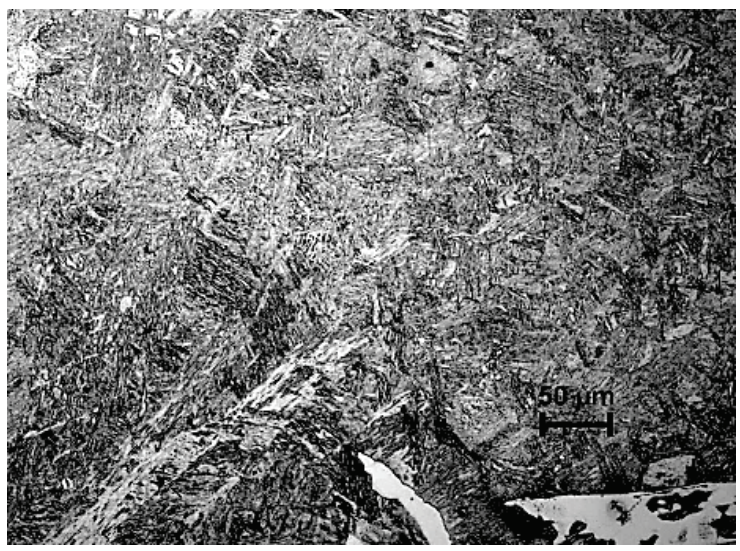

a)

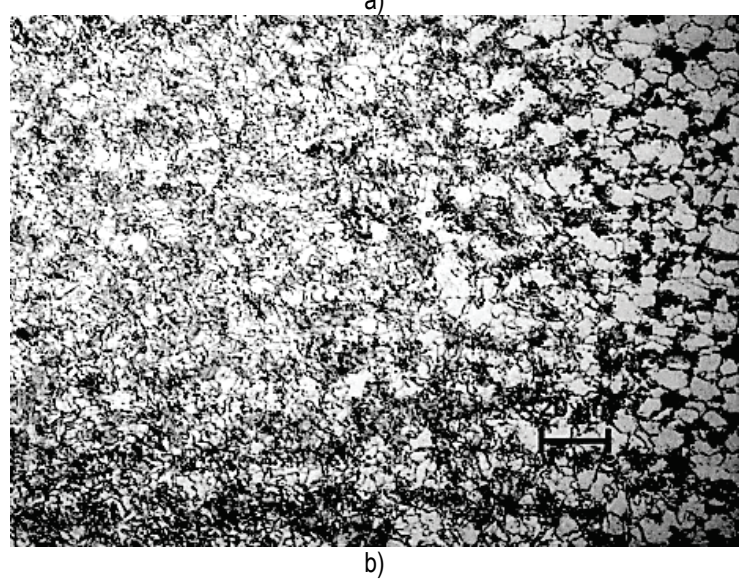

Figure 11 Structure of the joint from the side of mild steel H340LAD+Z140-M-B$0:$ a) highly-heated $H A Z$, b) $H A Z$ heated between $A_{c 3}$ and $A_{c 1}$.

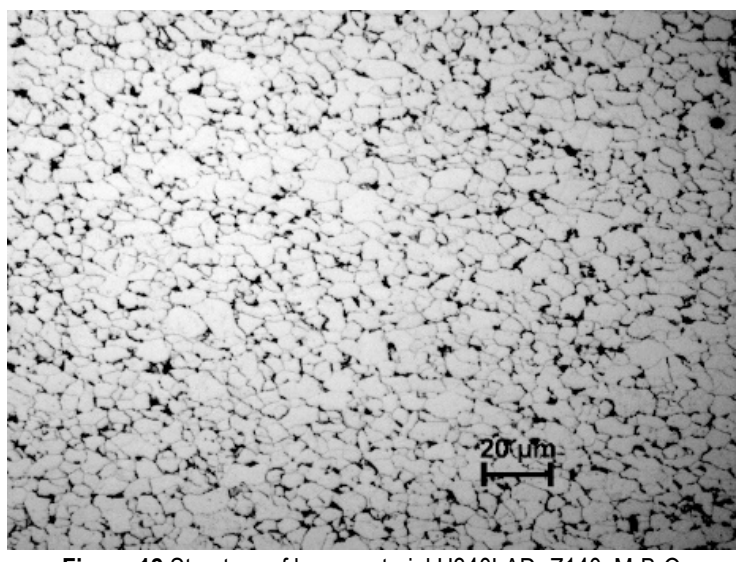

Figure 12 Structure of base material H340LAD+Z140-M-B-O

HAZ from the side of mild steel H340LAD+Z140-MB-O was influenced not only by the high cooling rate, but also a change in the chemical composition, especially in carbon content. Mixing the material with low carbon content (H340LAD + Z140-M-B-O) with the material with higher carbon content (USIBOR 22MnB5 + AS150) in the weld metal has caused the formation of the hard martensitic structure with high hardness. One can conclude that for the high welding temperature the $\mathrm{C}$ diffusion from the weld metal into CG HAZ of mild steel H340LAD-Z140-M-B-O will occur. Carbonisation and overheating of the material to a high temperature have led to creation of the multiphase structure with an increased representation of the upper bainite and martensite (Fig. 11). This corresponded 
to the CG HAZ hardness whose average value was 330HV0.2 (Fig. 6).

$\mathrm{HAZ}$ area heated between temperatures $\mathrm{A}_{\mathrm{c} 3}$ and $\mathrm{A}_{\mathrm{c} 1}$ was characteristic by a significant decrease of the grain size (Fig. 6). The main structural components are ferrite and transformed perlite (Fig. 11b), which led to a fall in the average value of hardness 230HV0.2.

The BM of galvanized mild steel H340LAD+Z140-MB-O had a ferrite - perlite microstructure with average hardness 160HV0.2 (Fig. 12).

\section{CONCLUSIONS}

From the obtained results, we can make the following conclusions:

1) When welding combined joints of galvanized mild steel H340LAD + Z140-M-B-O and high-strength micro-alloyed steel USIBOR 22MnB5 coated by Al-Si we did not observe contamination of joint by $\mathrm{Zn}$ coating. The reason is the low evaporation temperature of $\mathrm{Zn}$, which is more than $600{ }^{\circ} \mathrm{C}$ below the melting temperature of low carbon steel. In the weld structure, however, we identified inclusions with a high content of $\mathrm{Al}$, whose source is the coating of welded highstrength material. The cause of contamination is the formation of $\mathrm{Al}_{x} \mathrm{Fe}_{y}$ phases during thermo-mechanical treatment (hot pressing) with the evaporation temperature above $2000^{\circ} \mathrm{C}$.

2) In assessing the properties of weld nugget we assumed that the weld metal was created by mixing of molten material of mild and high-strength micro-alloyed steels in a ratio of $1 / 1$. Despite this assumption, the difference in hardness of the weld metal structure and highlyheated HAZ from the side of high-strength microalloyed steel USIBOR was small (CG HAZ hardness ranged from $410 \mathrm{HV} 0.2$ to $520 \mathrm{HV} 0.2$, the average hardness of WM was 445HV0.2). The high cooling rate of the material with a high carbon content $(\mathrm{C}=$ $0.2 \%, \mathrm{CE}(\mathrm{IIW})=0.62 \%)$, resulted in the formation of martensitic structures in WM and CG HAZ. The critical areas from the side of the high-strength microalloyed steel seem to be the HAZ area, where the heating of the material just below $A_{c 1}$ occurred. The zone is characterized by a significant drop in hardness (290 to $340 \mathrm{HV} 0.2$ ), structure is here composed of ferrite and tempered martensite. The criterion of the maximum hardness of the weld joint (550 HV 0.2) from the side of the high-strength steel USIBOR was met according to DVS 2902-2 and DVS 2905.

3) Hardness of HAZ from the side of mild steel from weld towards BM has steadily decreased. The cause of increased hardness CG HAZ (330HV0.2) was martensitic - bainitic structure. The final properties of CG HAZ have been caused by the partial carbonisation and high cooling rate. Hardness of BM (160HV0.2) corresponded to the original ferrite - perlite structure.

The results given in this paper were obtained as part of research project VEGA 1/0385/15.

\section{REFERENCES}

[1] Tumuluru, M. (2007). The effect of coatings on the resistance spot welding behaviour of $780 \mathrm{MPa}$ Dual-Phase steel. Welding Journal, 86, 161-169.

[2] Matthews, A. E. \& Davies, G. M. (1997). Precoated steel development for the automotive industry. Proceedings of the institution of mechanical engineers, 211, Part D, 319-324. https://doi.org/10.1243/0954407971526461

[3] http://www.arcelormittal.com (Accessed on 05.09.2016).

[4] Alenius, M., Pohjanne, P., Somervuori, M., \& Hanninen, H. (2006). Exploring the mechanical properties of spot welded dissimilar joints for stainless and galvanized steels. Welding Journal, 85, 305-313.

[5] Marashi, P., Pouranvari, M., Amirabdollahian, S., Abedi, A., \& Goodarzi, M. (2008). Microstructure and failure behaviour of dissimilar resistance spot welds between low carbon galvanized and austenitic stainless steels. Materials Science and Engineering A, 480, 175-180. https://doi.org/10.1016/j.msea.2007.07.007

[6] Liao, X., Wang, X., Guo, Z., Wang, M., Wu, Y., \& Rong, Y. (2010). Microstructure in resistance spot welded dual phase steel. Material characterization, 61, 341-346. https://doi.org/10.1016/j.matchar.2009.12.018

[7] Jong, Y. S., Lee, Y. K., Kim, D. Ch., Kang, M. J., Hwang, I. S., \& Lee, W. B. (2011). Microstructural evolution and mechanical properties of resistance spot welded ultra-high steel containing boron. Materials Transactions, 52(6), 13301333. https://doi.org/10.2320/matertrans.M2011005

[8] Khan, M. I., Kuntz, L. M., Biro, E., \& Zhou, Y. (2008). Microstructure and mechanical properties of resistance spot welded advanced high strength steels. Materials Transactions, 49(7), 1629-1637. https://doi.org/10.2320/matertrans.MRA2008031

[9] Livelli, G. \& Langill, T. (1998). Guidelines for Welding Galvanized Steel. PCI Journal, May-June, 40-48. https://doi.org/10.15554/pcij.05011998.40.48

[10] Sejč, P., Belanová, J., \& Kubiček, R. (2011). Utilization of Plasma Arc at the Metallurgical Joining of Zinc Coated Plates to Aluminium. Metallic Materials, 49, 6, 437-450. https://doi.org/10.4149/km_2011_6_437

[11] Yang, Y. S. \& Lee, S. H. (1999). A study on the joining strength of laser spot welding for automotive applications. Journal of Materials Processing Technology, 94, 151-156. https://doi.org/10.1016/S0924-0136(99)00094-1

[12] Meško, J., Zrak, A., Mulczyk, K., \& Tofil, S. (2014). Microstructure analysis of welded joints after laser welding. Manufacturing Technology: Journal for science, research and production, 14(3), 355-359.

[13] Zhang, H. \& Senkara, J. (2012). Resistance welding. Fundamentals and applications. CRC Press, Abington, UK.

[14] Tumuluru, M. (2007). The effect of coatings on the resistance spot welding behaviour of $780 \mathrm{MPa}$ Dual-Phase steel. Welding Journal, 86, 161-169.

[15] Marder, A. R. (2000). The Metallurgy of Zinc coated Steel. Progress in Materials Science, 45, 191-271. https://doi.org/10.1016/S0079-6425(98)00006-1

[16] Sueriho, M., Kusumi, K., Miykoshi, T., Maki, J., \& Ohgami, M. (2003). Properties of Aluminium-coated Steels for Hotforming. Nippon steel technical report, 88, 16-21.

[17] Yurioka, N., Okumura, M., Kasuya, T., Cotton, H. J. (1987). Prediction of HAZ hardness of transformable steels. Metal Construction, April, 217-223.

[18] Kolařík, L., Sahul, M., Kolaříková, M., Turňa, M., \& Felix, M. (2012). Resistance Spot Welding of dissimilar Steels. Acta Polytechnica, 52(3).

[19] Raoelison, R., Fuentes, A., Rogeon, Ph., Carré, P., Loulou, T., Carron, D., \& Dechalotte, F. (2012). Contact conditions on nugget development during resistance spot welding of $\mathrm{Zn}$ 
coated sheets using rounded tip electrodes. Journal of Materials Processing Technology, 212, 1663-1669.

https://doi.org/10.1016/j.jmatprotec.2012.03.009

[20] Hamidinejad, S. M., Kolahan, F., \& Kokabi, A. H. (2012). The modeling and process analysis of resistance spot welding on galvanized steel sheets used in car body manufacturing. Materials and Design, 34, 759-767.

https://doi.org/10.1016/..matdes.2011.06.064

[21] Moshayedi, H. \& Sattari-Far, I. (2014). Resistance spot welding and the effects of welding time and current on residual stresses. Journal of Materials Processing Technology, 214, 2545-2552. https://doi.org/10.1016/j.jmatprotec.2014.05.008

[22] Kim, E. \& Eagar, T. W. (2015). Interfacial Temperature Profiles in Simulated Resistance Spot Welding of Bare and Zinc-Coated Steel. Welding Journal, 94, 35-43.

[23] Standard VW 01105-1: 2007. Resistance Spot Welding. Design, Calculation. Uncoated and Coated Steel Sheets.

[24] Standard DIN - DVS 2902-2. Resistance Spot Welding of Steels with Individual Thicknesses of up to $3 \mathrm{~mm}-$ Spot Weldability.

\section{Contact information:}

Pavol SEJČ, Prof. Ing. PhD.

Faculty of Mechanical Engineering,

Slovak University of Technology in Bratislava,

Institute of Technologies and Materials,

Námestie Slobody 17, 81231 Bratislava 1, Slovakia

E-mail: pavol.sejc@stuba.sk

tel.: +421905326211-374

Judita BELANOVÁ, Ing. PhD.

Faculty of Mechanical Engineering,

Slovak University of Technology in Bratislava,

Institute of Technologies and Materials,

Námestie Slobody 17, 81231 Bratislava 1, Slovakia

E-mail: judita.belanova@stuba.sk

tel.: +421905326211-335

Štefan EMMER, doc. Ing. PhD.

Faculty of Mechanical Engineering,

Slovak University of Technology in Bratislava,

Institute of Technologies and Materials,

Námestie Slobody 17, 81231 Bratislava 1, Slovakia

E-mail: stefan.emmer@stuba.sk

tel.: +421905326211-344 